ニュートンの反復法公式により

$\left(\tan \phi_{1}\right)_{n+1}=\left(\tan \phi_{1}\right)_{n}-\left[F\left(\tan \psi_{1}\right)_{n} / F^{\prime}\right.$

$$
\left.\times\left(\tan \phi_{1}\right)_{n}\right]
$$

たたし $\left(\tan \psi_{1}\right)_{n}$ は第 1 近似， $\left(\tan \phi_{1}\right)_{n+1}$ 第 2 近

似,これより

$\left(\tan \psi_{1}\right)_{n+1}=\left(\tan \psi_{1}\right)_{n}$

$-\left[\frac{\cos \Sigma+m_{g}+\sin \Sigma\left(\tan \psi_{1}\right)_{n}}{\sin \Sigma+A\left(\cos ^{3} \psi_{1}\right)_{n}\left[\cos \Sigma\left(\tan \psi_{1}\right)_{n}-\sin \Sigma\right]}\right.$ $A\left(\cos \psi_{1}\right)_{n}\left[\cos \Sigma+\sin \Sigma\left(\tan \psi_{1}\right)_{n}\right]$

$\left.\sin \Sigma+A\left(\cos ^{3} \phi_{1}\right)_{n}\left[\cos \Sigma\left(\tan \psi_{1}\right)_{n}-\sin \Sigma\right]\right]$

第 1 近似の $\left(\tan \phi_{1}\right)_{n}$ は図式に求める. そして第 2 近 似，第 3 近似と次第に精度を高めてゆく，とくに $\Sigma=$ $90^{\circ}$ の時は

$$
\begin{aligned}
& \left(\tan \psi_{1}\right)_{n+1}=\left(\tan \phi_{1}\right)_{n} \\
& -\frac{m_{g}+\left(\tan \psi_{1}\right)_{n}-A\left(\sin \psi_{1}\right)_{n}}{1-A\left(\cos ^{3} \psi_{1}\right)_{n}}
\end{aligned}
$$

そして最後に $\Sigma=90^{\circ}$ の場合の数值例を一つ与えてこ の新しい解法を县体的に説明している。[而角宗倩]

\subsubsection{1}

※[264] 小形冷凍機用圧縮機の損失 [F. Pearson, Engineering, 1958-10-10, Vol. 186, No. 4831, p. 485 488, 因 13] 1/8P 家庭用冷凍機压縮機の葉形 (reed) 弁の作動を研究している. 王縮機の高速化に 伴い, モータ直結形とし, 冷媒の漏れ, 騒音等の点で は改善されたが他方容積効㻭は低下している。その原 因として, シリンダとの熱伝達, 弁の絞り賣失, 弁閉そ く時の逆流，弁座との密着不良等を調べた結果，吸入 弁の閸そく時の逆流が最大の原因であることがわかっ

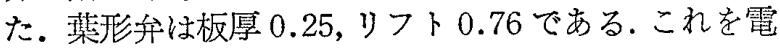
磁石により吸入の終る下死点の前後において強制的に 閉そくさせると，ちょうど下死点にて磁石を働かせた 場合に最も風量が多く，磁石の無い埸合よりも約 $5 \%$ 容積効率が高い。次に熱線風速計を吸入弃座に取付け て運転時の流速の变化と, 容量変化を利用した弁の運 動とを同時にブラウン管に入れて調べた。めいりょ うに逆流ならびに閉じおくれが認められ，逆流は弁の リフトおよび板愿が増し，吸入王力が低いほぼ大きく なり，吸入風量の 5〜10\%に達する。高透機において は弁板厚を 0.2 以下にしリフト $0.3 〜 0.5$ 程度にする と容積效率は大幅に改善しうるという結果が示されて いる. [大谷装]

621.181.64: $536.248 .2: 536.423 .1$

※[265] 揮発性添加物の ある水の 沸騰熱伝達 [G. Leppert, C.P. Costello, \& B.M. Hoglund, Trans. ASME., 1958-10, Vol. 80, No. 7, p. 1395 1404] 垂直なダクトを蒸留水が下から上に流れこの中に水平 におかれた外径 0.11 in, 肉厭 0.011 in のステンレス 管を交流で電気的に加熱し，管表面で淽騰が行われて いるとき水にわずかにアルコールを加えると熱伝達率 および気注うの平均直彽がどのように変化するかにつ いて研究している。

約 1\%のイソプロピルアルコールまたは $2 \%$ のメチ ルアルコールを加えても核沸騰熱伝達率はほとんど変 化しはいが，気ほうの平均㨁圣は Bonilla \& Perry 等 の実験式で予測されるものよりも著しく小さくなり，
水玲却原子炉の場合密度分布, 平均密度および王力椇 失等の点で有利となる。

また熱伝達についてはその熟流束を刘流によるもの と沸㥢によるものの二つに分ける Rohsenow の方法 がよい結果を示している。

[福茾 凟夫]

532.517.2:536.242: 538.665

※[266]平板間層流熱伝達に及ぼす磁場の効果 〔R. Siegel, J. Appl. Mech., 1958-9, Vol. 25, No. 3,

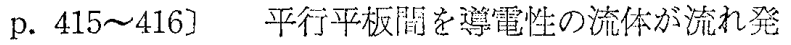

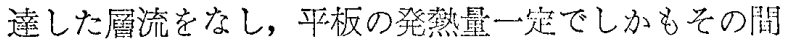
に磁場があるため流体の内㲅にも発熱のある場合の壁 混と流体平均温度との差它計算によって求好ている。 結果は次式で表わされる。

$$
\begin{aligned}
& \frac{t_{w}-t_{m}}{\left(t_{w}-t_{m}\right)_{M=0}}=\frac{35}{17} \\
& \quad \times\left[\Phi(M)+\frac{\kappa}{q L} \frac{\left(R_{e} P_{r}\right)^{2} \nu \alpha}{8 L^{2} c p} \chi(M)\right]
\end{aligned}
$$

$t_{w}$ : 壁温, $t_{m}$ : 流体の严均温度, $\left(t_{w}-t_{m}\right)_{M=0}$ は磁場 のない場合 $=17 q L / 35 \kappa, M:$ 粘性力と磁場による粘 性打比， $\Phi(M), \chi(M)$ は $M$ の特望の関数, $\kappa$ :

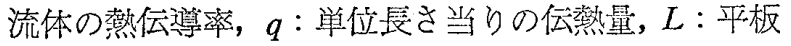
間げきの斗分の長さ, $R_{e}:$ レイルズ数 $V \cdot 2 L / \nu$, $V$ は流速, $\nu$ : 流体の勳粘性係数, $P_{r}$ : プラントル数, $\alpha:$ 温度伝導率, $c_{p}:$ 比熱である。

プラントル数の小さい液体金属では右辺第 2 項は小 さく,たとえば $M=10$ では $\left(t_{w}-t_{m}\right) /\left(t_{w}-t_{m}\right)_{M=0}=$ $35 / 17 \Phi(M)=0.8$ となる。 [福井 資夫]

\subsubsection{6: 536.242}

※[267]気流に平行におか礼た線の熱伝達に及活す据 動の影響 [R. Anantanarayana \& A. Ramachandran, Trans. ASME, 1958-10, Vol. 80, No. 7, p. 1426 1432]正徍 0.018 in のニクロム線を電 気で加熱し，気流と平行にお导振動させたときの笳伝 達について夷験を行っている。

気流の速さは 34〜 $63 \mathrm{ft} / \mathrm{s}$ ，振骾は 75〜120 サイク ルで振動数および振幅の堛加とともに熟伀達率は堷 し，大きなときには $130 \%$ も增す。，その閦係は次式に て示されている。

$$
\frac{\left(N_{u}\right)_{V}}{\left(N_{u}\right)_{n}}-1=4.25\left[\frac{\left(R_{e}\right)_{V}}{\left(R_{e}\right)_{f}}\right]^{0.977}
$$

$\left(N_{u}\right) v=h v d / K$ : 振動する線のヌセルト数, $\left(N_{u}\right)_{s}$ $=h_{s} d / K$ : 静止している楾のヌセルト数, $\left(R_{e}\right)_{V}=$ 振

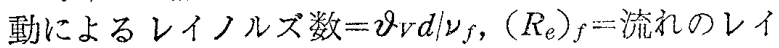

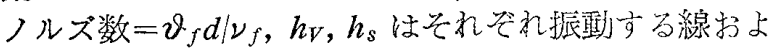

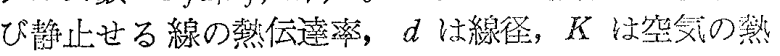

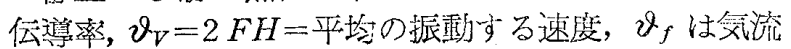
の速度, $\nu_{f}$ は空気勤粘性係数。

ただしここで $\left(N_{u}\right)_{s}=0.0522\left(R_{e}\right)_{f}^{0.729}$ で与えられ ている.

[福井 凟夫]

\section{$662.612 .31: 536.46$}

[268] ブンゼン火炎の流れの場 [M.S. Uberoi， A.M. Kuethe, \& H.R. Menkes, Phys. Fluid, 1958 $-3 / 4$, Vol. 1, No. 2, p. 150 158, 図 13] $こ の$ 論文は火炎をともなった流れの場の一例として，二次 元のブンゼン火炎の定常的な流れの場を考え, 火炎の

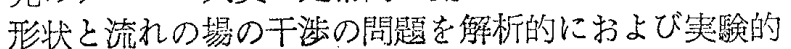

